\title{
Cenozoic Basins of the South China Sea
}

\section{by Wu Jinmin}

The South China Sea is a region of greatly varying crustal structures, extensive tectonic activity and complex geophysical and geomorphological features. Cenozoic sediments are well developed, and the area has been the recent target of intense exploration for oil and gas. This article, presented at a recent IUGS seminar in Guangzhou, reviews current ideas on the evolution and hydrocarbon resources of the South China Sea. (Ed.)

\section{Cenozoic Basins of the South China Sea}

The Cenozoic deposits of the South China Sea are dominated by unmetamorphosed clastic sediments, with volcaniclastic rocks well developed in the east, and carbonate rocks in central portions in the regions of Dongsha, Xisha, Zhongsha, Nansha and the offshore of Palawan (Figs. 1 and 2). Based on geological and geophysical data, some 37 Cenozoic sedimentary basins or groups of basins have been recognized in the South China Sea (Fig. 2), in about 18 of which oil and gas have been found. The maximum thickness of Cenozoic sediments here is over $10,000 \mathrm{~m}$, and studies of their depositional characteristics are of obvious importance to the development of exploration for oil and gas in the region.

In broad order of stratigraphic sequence, six major depositional areas can be recognized (Fig. 1). In the Beibuwan Zhu-3 Depression Tertiary strata, especially lower Tertiary, are developed completely and exhibit characteristic rhythms and cycles. These rocks are primarily terrest rial facies with greatly varying thickness, whereas the upper Tertiary strata are dominated by clastic sediments of neritic facies.

In the Western Area, upper Tertiary strata are better developed than those of the lower Tertiary. Lower Palacogene deposits are thin or absent but terrestrial-transitional sediments accumulated during early Tertiary time, changing to marine facies during the late Tertiary. This marine transition is more obvious from west to the east where clastic rocks predominate. Carbonate rocks are distributed locally, and Upper Miocene strata are missing in places.

The Southern Area is situated south of the Nansha Islands and the Nansha (Palawan) trough, but it excludes the North Palawan Basin. Lower Tertiary strata here (the Ranjang Group in Sarawak and the Crocker Formation in Sabah) are composed of flysch and ophiolite formations, slightly metamorphosed to phyllite and slate and severely folded into steeply dipping and imbricated structures. Upper Tertiary strata (including Upper Oligocene in parts) are fully developed here and are composed of shallow clastics with carbonate intercalations. Upper Miocene regressive deltaic sediments are broadly developed.

The Eastern Area comprises the Philippines and offshore areas, where lower Tertiary strata have been folded and metamorphosed. Upper Tertiary (including Upper Oligocene) deposits contain abundant volcanic rubble and other volcanies, with a maximum thickness over $15,000 \mathrm{~m}$.

The Xisha-Nansha areas include Zhongsha, North Palawan and adjacent areas. Lower Tertiary deposits here are not so well developed, though a relatively complete clastic section of early Tertiary age has been found in Liyue (Reed) Bank. Carbonate rocks of late Tertiary age are more fully developed.

The Deep-Sea Basin is underlain by the oceanic erust. Sedimentary strata here are dominated by upper Tertiary (including Upper Oligocene) and Quaternary unconsolidated abyssal ooze and volcanic deposits.

As mentioned above the depositional environments in the marginal areas of the South China Sea changed greatly from Palaeocene-Eocene to Late Oligocene. Four major stages in the Cenozoic development of the region can be distinguished as follows.

\section{Eocene Depositional Environments}

During Eocene time (Fig. 3) there were three uplifts, on the northern margin of the South China Sea: Wanshan-Hainan, Shenhu-Xisha, and Penghu-Dongsha. These NE-SW uplifts were separated by depressions consisting of a series of small sags. Some of these also occur within the uplifts and contain well-developed fluvial-lacustrine deposits. The sediments thin from west to east in these depressions. The present Taixinan Basin appears to have then been part of the Penghu uplift, for it did not receive deposits at this time. Southwest of Hainan, the Yinggehai Basin consisted of NWSE lacustrine basins, into which the Red River flowed.

The continental margin of the southern South China Sea during Eocene time was divided by the Vatuna uplift (Fig. 2) into western and eastern parts, each with quite different sedimentary environments (Fig. 3). To the west, the Culf of

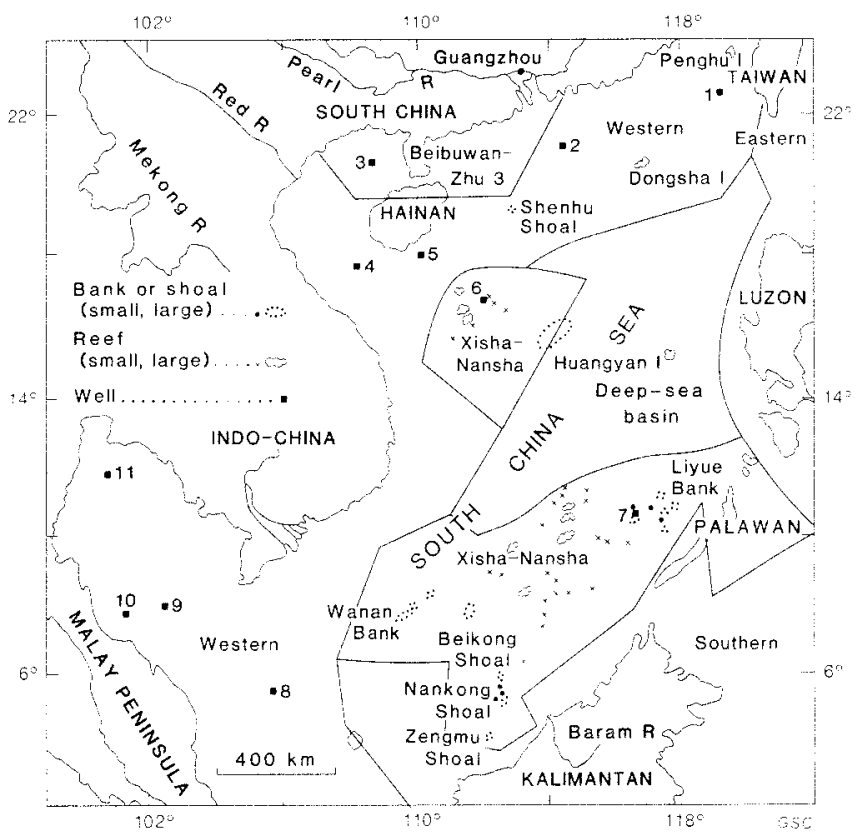

Figure I: Distribution of Cenozoic sedimentary areas (underlined) of the South china sea. Some important wells are shown: 1-CF-1; 2- Zhu 5; 3- wan 2; 4- Ying 2; 5- Ying 9; 6- Xiyoug 1; 7- Sampaquita: $8-A Q-4 ; 9-16-B-1 ; 10-16-C-1 ; 11-4-B-1$. 


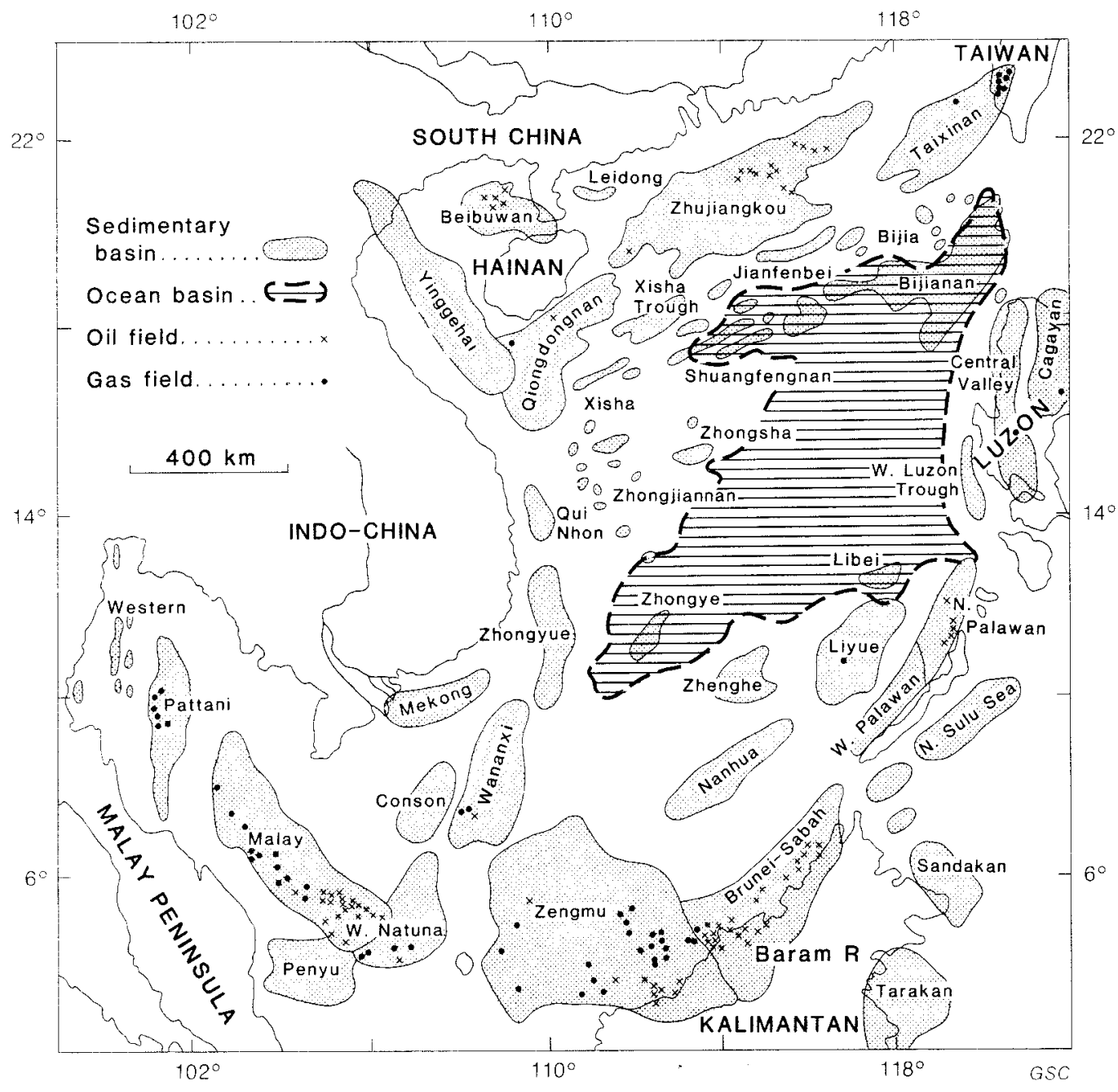

of the Giongdongnan and Yinggehai basins were then joined, but the transgression stopped short of the northwest end of the latter basin. Transitional and littoral deltaic sediments occur in the Hanoi Depression of Vietnam (Skorduli et al., 1983).

The marine transgression in the Beibuwan Basin occurred slightly later. The Upper Oligocene rocks here consist of nonmarine assemblages characterized by spore-pollen and freshwater ostracoda, whereas the marine Xiayang Formation is only equivalent in age to the late Early Miocene (top of nannofossil zone NN3-NN4, according to Duan el al., 1987). Littoral-neritic sandstones and mud stones predominate in the wide continental margin of the northern South China Sea, but in uplifts such as Dongsha, Shenhu, Xisha, and along the south edge of the Hainan uplift, carbonate rock and reefs are extensively developed. West of Natuna the area was dominated by transitional deposits of fluvial-lacustrine and littoral-swamp facies (Woollands and Haw, 1976). Higher in the sequence marine facies occur in western Natuna, with fine dark mudstone containing

Figure 2: Cenozoic sedimentary basins of the south China sea showing oil and gas fields. After wu (1987).

Thailand was then a landmass, though fluvial-lacustrine deposits may have formed then in the separated Pattani, Valay and West Natuna basins (Fig. 2). The Wananxi Basin might have been a deltaic deposit related to the Mlekong River. Abyssal flyseh deposits formed at this time in Sarawak, Brunei, Sabah and south Palawan (Haile, 1974), and sand, mud and carbonates, ranging from littoral to abyssal facies, were deposited on the Nansha massif, including the liyue Bank and the west edge of North Palawan Island (Fig. 1).

\section{Late Oligocene to Early Miocene Environments}

The continental margin of the northern South China Sea underwent widespread marine transgression following Late Oligocene time, resulting in a substantial decrease in the area of the Wanshan-Hainan, Shenhu-Xisha, and PenghuDonosha uplifts (Figs. 1 and 4). Sediments deposited during this transgression become younger to the northwest, with the earliest marine sedimentary record in the Taixinan Basin dating from about the NP 22 zone (lluang, 1982). In the Zhujianckou Basin sediments are equivalent to the calcareous nannofossil zones NP 24-NN3. The northern edge of this marine transgression is situated near the Zhu 5 well (Fig. 1), and the separate depressions and sags that existed here in the Eocene (Fig. 3) were unified into a single basin during Oligocene time.

Evidence of a subsidiary transg ression has been found in the ciongdongnan Basin coming from the Xisha Trough (Fig. 2), where nannofossil zone NP 25 was discovered. The waters coal and plant debris dominating the center of each basin. There may also be marine intercalations with planktonic foraminifera in the southeastern Malay Basin (Armitage and Viotti, 1977). Littoral marine carbonates predominate east of Natuna and over the Nansha area and Liyue massif, whereas bathyal clastics occur between the carbonate
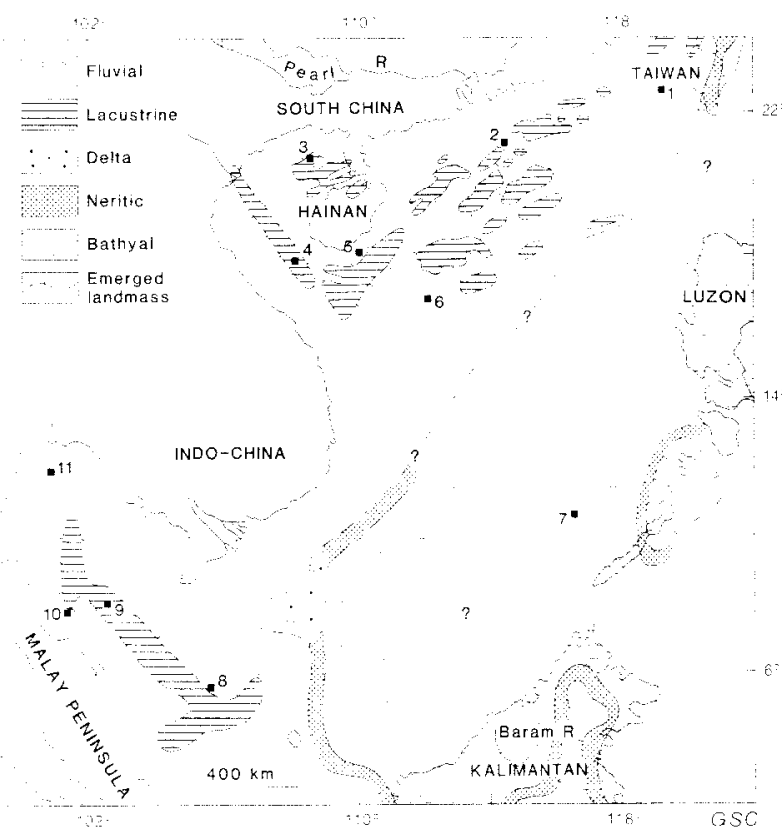

Figure 3: Eocene depositional facies of the South China Sea. Solid squares - wells as in Figure 1. 
platforms. The southern boundary of Zengmu and BruneiSabah basins shifted northward, as Kalimantan Island rose, and coastal littoral-neritic and bathyal facies clastic sediments were deposited from south to north in these basins. The Zengmu Basin sloped eastward and accumulated littoral-neritic sediments.

\section{Middle to Late Miocene Deposition}

As the marine transgression spread farther inland over the continental margin of the northern South China Sea during Middle to Late Miocene time, the uplifts were further submerged (Fig. 5). The northern boundary of the coastline was submerged to almost the present $30 \mathrm{~m}$ water depth line, and the whole area was dominated by neritic clastics, except for some uplifts containing carbonates.

A broad area of the continental margin rose during the early Late Miocene time, and most of the uplifts (e.g. Dongsha and Shenhu) again emerged above sea level and were eroded. A sedimentary hiatus occurred in each basin, and nannofossil zones NN9-NN10 and lower NN11 are absent.

In the Nansha area, including the Nankong and Beikong platforms (Central Luconia) of the Zengmu Basin (Figs. 1 and 2), a littoral-neritic depositional environment still prevailed, with carbonates and reefs developed mainly on platforms surrounded by deeper water clastics. Deltaic deposits formed at the mouth of the Baram River of the Brunei-Sabah Basin during late Middle to Late Miocene time, while a turbidite fan deposit dominated offshore Sabah (ASCOPE, 1981). In the Gulf of Thailand the ancient coastline moved westwards to the center of the Malay Basin, and marine sediments were widely deposited in the Mekong and Malay basins.

\section{Pliocene-Quaternary Envi ronments}

The transgression reached its maximum extent along the continental margin of the northern South China Sea during Early to Middle Pliocene time (Wu, 1985), when the ancient coastline was at almost the same location as at present, and when all of the uplifts had been submerged again, except for Hainan Island. Neritic and shelf clastics dominated during this interval, but south of Hainan and Taiwan rapid subsidence took place, with from 3000 to $5000 \mathrm{~m}$ of bathyal clayshale deposited (Chou, 1971, 1973).

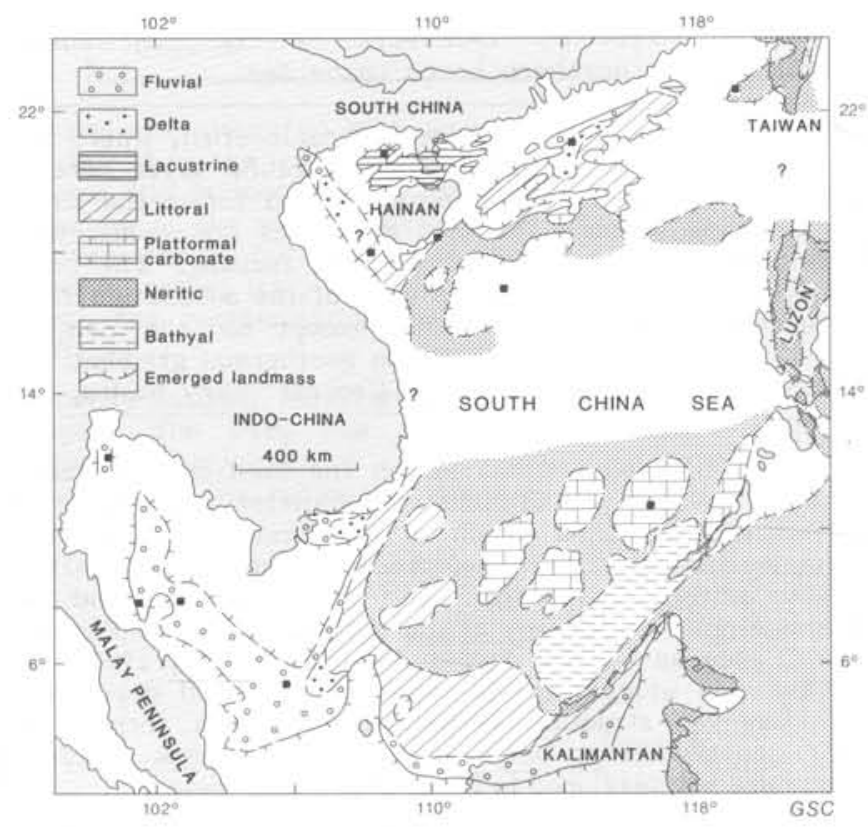

Figure 4: Late Oligocene depositional facies of the South China Sea. Solid squares - wells as in Figure 1.
In the south, the depositional center of the Zengmu and Brunei-Sabah basins moved farther seaward due to the rising of Kalimantan, and littoral-neritic clastic deposits predoninated, with neritic carbonates developed in Liyue and North Palawan basins. West of the Natuna uplift, the Pattani, Malay, and West Natuna basins were by this time submerged, though not to great depths, and littoral-neritic clastics were again being deposited. The eastern part of the Natuna-Khorat (NE Thailand) uplift has subsided rapidly, since the Early Quaternary, and deposits up to $1500-2300 \mathrm{~m}$ thick accumulated.

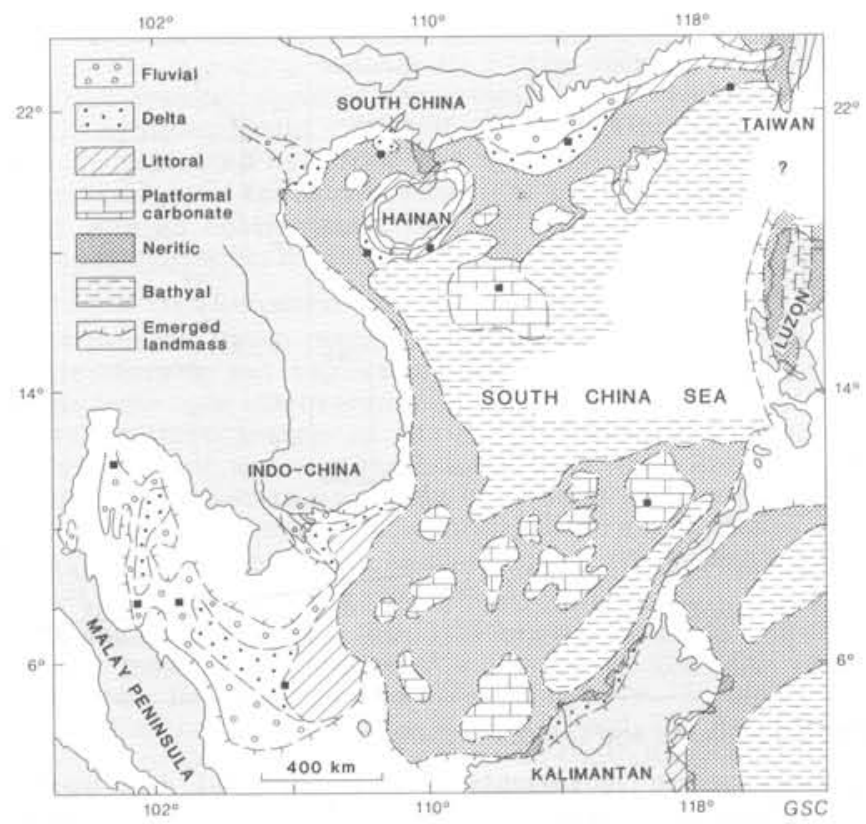

Figure 5: Middle Miocene depositional facies of the South China Sea. Solid squares - wells as in Figure 1 .

\section{Cenozoic Sedimentary Cycles}

In the northern part of the region, the Cenozoic sediments of the South China Sea can be divided into two sedimentary cycles, with the unconformity between Lower and Upper Oligocene deposits as the boundary. According to the data available, the basinal sediments changed progressively from terrestrial facies to marine facies from bottom to top along the continental margin of northern South China Sea. The typical sedimentary sequence is: red clastics (PalaeoceneLower Eocene), dark argillaceous lacust rine shales (Middle Eocene-Lower Oligocene), littoral plain and swamp coalbearing and biogenic bank formations (Upper Oligocene), littoral clastic formations and shallow bank carbonates (Lower-Middle Miocene), neritic and bathyal clastic formations (Upper Miocene-Quaternary). Figure 6 illustrates the mainly transgressive cycles, which began in Late Oligocene time. Of the three peaks - late Early Miocene, late Middle Miocene and Early Pliocene - the latter is the greatest one, characterized by abundant fossils and thick widespread and well-developed mudstones overlying older strata.

In the southern South China Sea the marginal basins formed later than those of the northern South China Sea. Data from the northern part of Kalimantan and its offshore area indicate that the Palaeocene-Eocene sequence here has been subject to regional metamorphism and folding (CCOP-IOC, SEATAR, 1980) and forms the present basement to the basins here. The following sedimentary sequence of regressive cycles from bottom to top is developed in these basins: abyssal flysch (Upper Eocene-Lower Miocene), neritic clastics and carbonates (Lower-Middle Miocene), deltaic and reef carbonate formations (Middle-Upper Miocene), and neritic and littoral clastics and carbonates (Pliocene- 
Quaternary). The Baram Delta has eight regressive cycles (ASCOPE, 1981) within the upper sedimentary cycle (Fig. 7). During the major regression of late Middle Hiocene-Late Miocene time, deltaic deposits were most extensive. The sedimentary characteristics in the southwest South China Sea are similar to those in the north, though the transgressions began later nere.

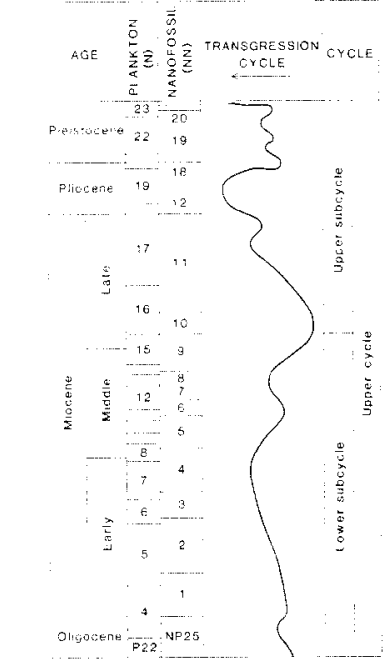

Figure 6: The upper sedimentary cycle (Cenozoic) of the northern South china sea (wu, 1987).

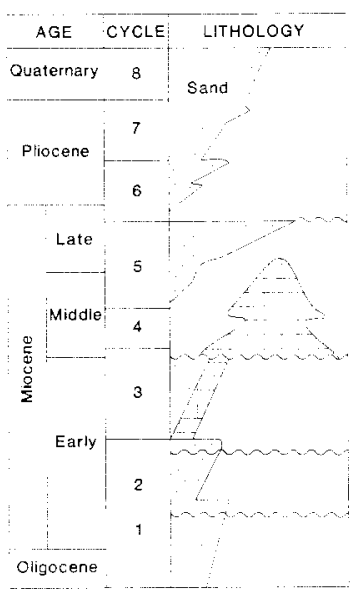

Figure 7: The upper sedimentary cycle in the $B$ a ram Delta of Kalimantan. After Ramli (1985).

\section{Plate Tectonics and Cenozoic Basins}

Cenozoic plate movements characteristic of the South China sea region are such that microplates, which earlier had been sutured together (e.g. South China, Indochina and Burma-iralay), have undergone a realignment process, involving extension-thinning, rifting-disintegration, strikeslip, and convergence and collision as a result of the collisions of the Indo-Australian and Pacific plates. The history of plate novement during the cenozoic tra here is marked by the Nanhai (South China Sea) movement, wnich occurred Detween Larly and Late Oligocene time. Juring this period subduction of oceanic erust in the ancient South Cnina Sea, continuing from the Late Cretaceous Period, was followed by spreading and formation of the modern South Cnina Sea after Late Oligocene time ( $W u, 1987$ ).

Development of the Cenozoic basins of the South Cnina Sea was inevitably controlled by the structural evolution of the area bordering the Deep-sea Oceanic Basin between XishaZhongsha and Luzon (Fig. 2). Based on the mechanisms of plate tectonics, these basins can be divided into four main categories as follows:

lensional structures: From late Mesozoic to early iertiary times, the northern South Cnina Sea was part of the continental margin of Andean-type that formed the eastern edge of Asia (Guo et al., 1983), but atter the Late Oligocene it became an Atlantic-type margin. As shown above, the continental margin in the northern South China Sea was successively controlled by tensional stresses from different directions throughout the Wesozoic-Cenozoic. Ihe overlap here of early NE to NNE extension fractures with later ones trending $\mathrm{ENE}-\mathrm{HSH}(\mathrm{Hig}, 8)$ led to a structural framework represented by zonal structures from north to south and blocky structures from west to east ( 1 u, 1985) that resulted in a series of extensional pasins, such as Beibuwan, Wiongdongnan, zhujiangkou, and Iaixinan (fig. 2 ).

These Harginal l'ension and Fracture Basins represent intraplate fractures and depressions (Table 1). Their extension was controlled by the spreading direction of the South China Sea, and their long axes are parallel to the shoreline.

Beneath the basins the crust has generally thinned to about $24 \mathrm{~km}$. In the early stages, separate depocenters existed, which coalesced subsequently to form the distinct basins (Figs. 9, 10). These have, therefore, a two-layered structure reflecting these two stages of development. The lower one (Late Cretaceous-Early Oligocene) is dominated by $\mathrm{NL}$ SW structures and is a product of rift-faulting, whereas the better developed upper one mainly consists of NNE-SSW structures produced during subsidence. Normal faults also developed, and horst-graben structures predominate in the basins. Basement uplifts are well developed as are "covering" structures, "buried hills" structures, and tilted fault block structures (Fig. 11).

Convergence Structures: Palaeomagnetic data show that in the early Palaeogene counterclockwise rotation took place in the western part of Kalimantan Island (Borneo microplate - $\left(50^{\circ}\right.$ according to Haile et al., 1977$)$ and in Luzon $\left(70^{\circ}-\right.$ Hsu and Scharon, 1970). I'nese formed respectively a convergent margin in the southern and an underthrustingcompressive margin in the eastern South Cnina Sea.

l'he extension direction of the basins in these regions is similar to that of the regional tectonic grain. In the southern South Cnina Sea the basins lie on thinned continental crust, where the Moho is at deptns of $2 u-22 \mathrm{~km}$. In the east

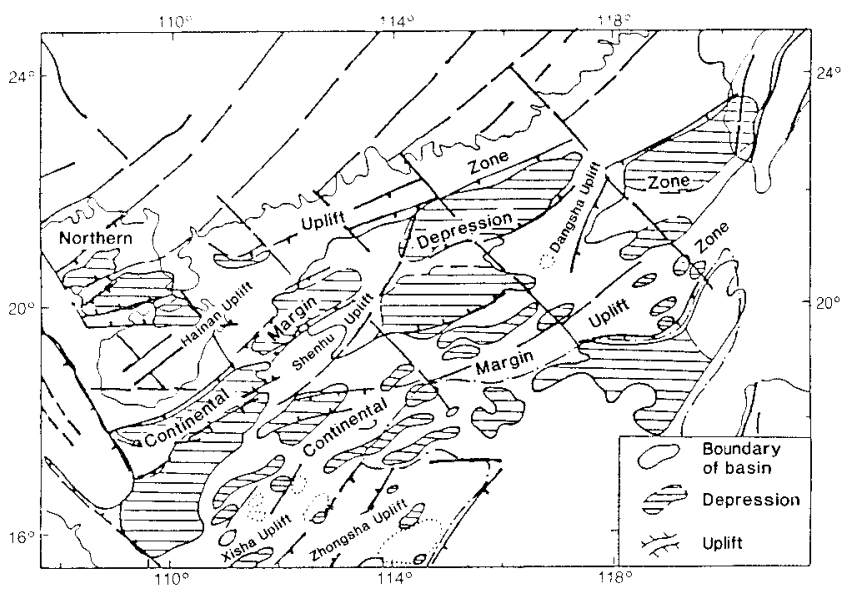

Figure 8: Tectonic framework of the continental margin of the northern South China Sea.

the basins formed on transitional oceanic crust, where the Hoho is $26 \mathrm{~km}$ deep. The lower structural layer here is generally folded and metamorphosed and forms the basement to the basins. The fold structures are youno, well developed, and associated witn thrust faulting. 'Ihe compressive basins located on the edge of the subduction zone have low geothermal gradients, except for the 'zengmu Basin, which has a $3.7-9.4^{\circ} \mathrm{C} / 100 \mathrm{~m}$ geothermal gradient. In the ivest Palawan, Cagayan and Central Valley basins, the gradient is less than $2.5^{\circ} \mathrm{C} / 100 \mathrm{~m}$.

The Zengmu Basin, which lies on the mild collision zone between the Nansha and Borneo microplates, is regarded as a Foreland Basin. It is obviously asymmetric, with the intensity and age of folding decreasing northward (ASCOPE, 1981). Between the Pacific plate subduction zone and the orogenic beit-volcanic arc of the Philippines lie the Forearc Basins such as Central valley (Bachman et al., 1983) and Cagayan, in which volcanic sediments are well developed. ine Cagayan structure is an interare basin formed by extension and rifting between two volcanic ares. Forearc basins are not developed in tne Brunei-Sabah region.

Iransformal Structures: Shear faults are well developed in western South China Sea. Tapponnier and otners (1982) have pointed out that the development of the Red River and Gulf of Thailand faults are related to the subduction of the Indian 


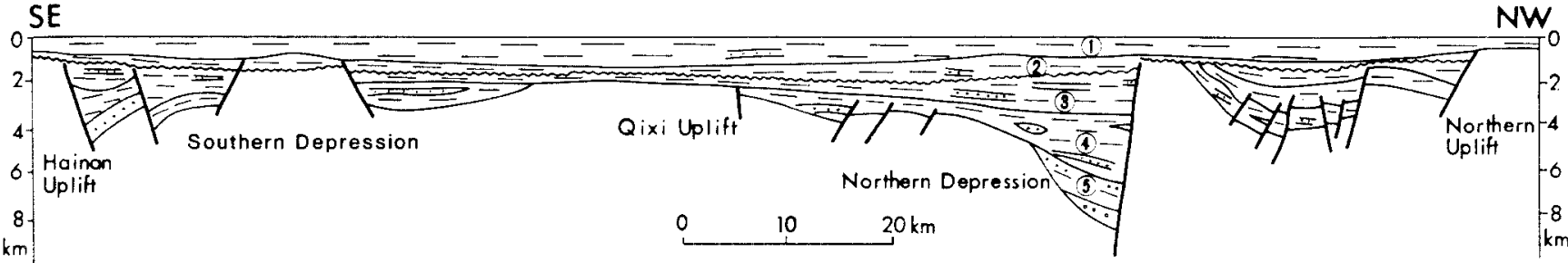

Figure 9: Interpreted seismic reflection profile across the Beibuwan Basin. $A$ fter $Z$ hai Guangmin and Oiu Zhongjian (1994). I-Middle Miocene to quaternary; 2- Lower to Middle Miocene; 3- Upper Oligocene to Lower Miocene; 4- Eocene to Lower Oligocene; 5- Palaeocene.

under the Eurasian plate (Fig. 12). According to them when the Indian plate underthrust northwards the Eurasian plate at $40 \mathrm{Va}$, major sinistral strike-slip faults developed, radiating eastwards from the subduction zone north of India. these faults made up several triangular continental blocks that widen from west to east, and which moved eastward or southeastward along the faults. 'ine general tendency of these lateral movements was an eastward squeezing out of southeast Asia, in a so-called "propagating extrusion tectonics" pattern.

The Cenozoic depressions that formed against this background are termed "Shearing Extensional Basins," such as $Y$ inggehai, Malay and West Natuna. 'The extension in these basins is controlled by regional structural lineations, and the

Table 1: Thickness of Cenozoic structural layers on the continental margin of the northern South China Sea.

\begin{tabular}{|c|c|c|c|c|c|c|}
\hline \multirow{3}{*}{$\begin{array}{l}\text { 'hickness } \\
\text { of structural } \\
\text { i. ayer }(\mathrm{m})\end{array}$} & \multicolumn{2}{|c|}{$\begin{array}{l}\text { Intra-plate } \\
\text { fracture } \\
\text { and } \\
\text { depression } \\
\text { basiis }\end{array}$} & \multicolumn{4}{|c|}{$\begin{array}{l}\text { Iarginal tension and } \\
\text { fracture basin }\end{array}$} \\
\hline & \multirow{2}{*}{ 离 } & \multicolumn{3}{|c|}{ Zhujiunirole } & \multirow{2}{*}{ 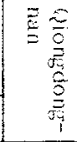 } & \multirow{2}{*}{ 焉 } \\
\hline & & zhu 3 & thu 1 & $\operatorname{cou} 2$ & & \\
\hline $\begin{array}{l}\text { Upper } \\
\text { Oligocene to } \\
\text { Quaternary }\end{array}$ & 3000 & $3 \supset 00$ & $50 \mathrm{~J} 0$ & tiono & 8000 & 9000 \\
\hline $\begin{array}{l}\text { Palacocene } \\
\text { to Lower } \\
\text { Oligocene }\end{array}$ & ธ่ง Uง & ouvi & 2000 & 3000 & 3000 & u \\
\hline
\end{tabular}

basins are elongated with no obvious separation features. within them the upper structural layer is dominant, and the lower one is incompletely developed. The basins become younger to the north. Reversed faults occur in addition to normal faults, but commonly the latter are older. Folds formed rather late, and mud diapirs are common. In gencral, the geothermal gradient is relatively hign in these basins.

Gravity-Settling Structures: These basins constitute two lypes. The Deep Sea Accumulational basins (e.g. the shuanfengnan) formed on oceanic crust that gradually subsided in the rifting and tension setting because of the increase in cooling and density of the oceanic crust, and on which younger deposits accumulated. The other type - the Rifted Block basins - formed on continental fragments that were separated by rifting and drifting. The Liyue Basin is an example of these structures that are underlain by oceanic or thinned continental crust and that are almost inactive and monotonous, dominated by normal faults.

\section{Oil and Gas Resources}

At present, seven countries bordering the South china Sea are carrying out exploration for hydrocaroons, and oil and gas have been discovered in most of the marginal basins. In the southern margin of the South China sea hydrocarbon development has continued for a long time, and extensive drilling has led to good results. During the period 1970 to 1980, about 1000 wells were drilled. In Pattani, Malay, West Natuna, Lengmu, Brunei-Sabah and North Palawan basins, 108 oil and gas fields have been discovered.

In the Sabah area of the Brunei-Sabah Basin, 60 structures have been tested, and 16 have yielded oil and gas. For the Zengmu Basin the comparable figures are 126 and 52 , for the Nankong and Beikong shoals 43 and 20 , for the Esso blocks of the Malay Basin 40 and 23 (ASCOPE, 1981). In the Thai portion of the Gulf of inailand 110 wells have been drilled, of which $b 2$ have produced natural gas with condensate and crude oil (Polahan, 1985). Overall, the success rates for the southern and western margins have averaged $40 \%$, with the range $27 \%$ (Saban) to $58 \%$ (Nalay Basin).

In the northern South China Sea encouraging results from oil and gas exploration have been acnieved, although the work here started rather late. In the Beibuwan, Yinggenai, Qiongdongnan, Zhujiangkou and Iaixinan Dasins, 162 wells have been drilled, including 14 by the U.S.S.R. in the Hanoi Depression of Vietnam (Skorduli et al., 1 y83). From these 32 oil and gas fields or hydrocarbon-bearing structures nave been discovered. In the Znujiangkou Basin, lo out of structures drilled have yielded oil and gas, and the comparable figures for Beibuwan are 6 and $1 b$, for a success rate of $38 \%$. The Wei 10-3 oil-field in the Beibuwan Basin was the first one put into production (on August $y, 1 y 86$ ), and to November 15, 1987, the accumulated oil output was 453 thousand tons, with 1140 million $\mathrm{m}^{3}$ of gas. The discoveries of the giant gas field $\mathrm{Ya} \mathrm{13-1}$ in the Qiongdongnan Basin and the sizeable oil field Liuhua $11-1$ in the Znujiangkou Basin are encouraging.

Experience so far indicates that basins with oil and gas in the South China Sea have higher geothermal gradients, except for the deep sea accumulational and forearc basins.

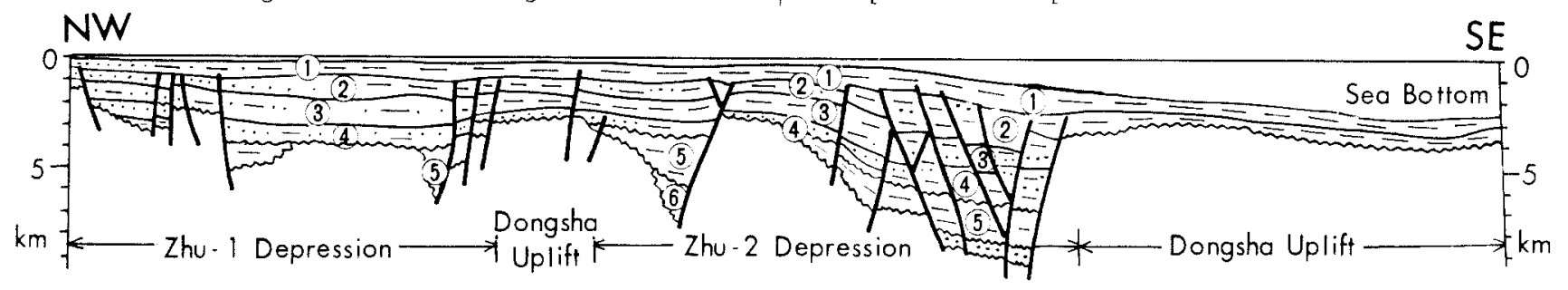

Figure 10: Interpreted seismic reflection across zhujiangkou Basin. After zhai Guangmin and oiu Zhongiian (1984). I- Upper Miocene to Quaternaru; 2- Middle Miocene; 3- Lower Miocene; 4- Upper Oligocene; 5-Palaeocene; 6- Upper Cretaceous. 


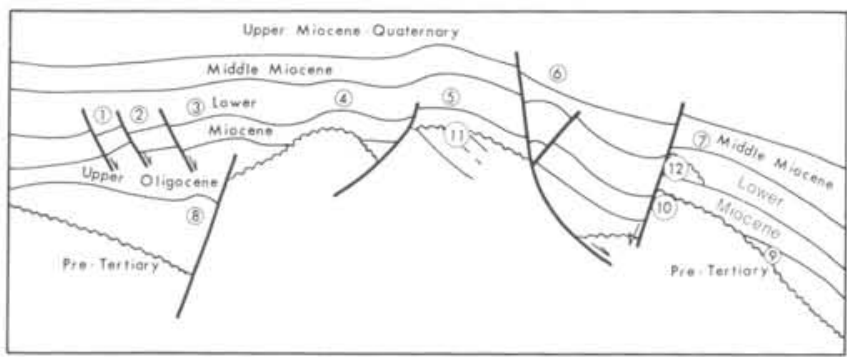

Figure 11: Schematic sketch of traps in the zhujiangkou Basin. 1- fault nose, 2- fault block, 3compressive anticline, 4- drape anticline, 5- growth anticline, 6- roll-over anticline, 7- semi-anticline, 8- rollover semi-anticline, 9- overtrap, 10buried hill, 11- unconformity, 12- reef. After zhai Guangmin and Qiu Zhongjian (1984).

Three source rock suites have been identified: Eocene, Upper Oligocene-Lower Miocene, and Middle-Upper Miocene. Reservoirs, which are dominated by clastics, are found in similar suites: Eocene, Upper Oligocene-Lower Miocene and Middle Miocene-Pliocene, with deltaic and turbidite sandstones and reef carbonates constituting important reservoir rocks.

Traps are related to fault blocks in the basement especially along the northern margin of the South China Sea. In the south, the traps are related to folding, growth faults and piercement structures. Oil and gas are spatially distributed in the margins of depressions or in slowly rising parts of the basins and the major gas-generating areas may be closely controlled by organic source and geothermal gradient.

In terms of their future prospects, the Zengmu, Zhujiangkou, Brunei-Sabah, Malay, Qiongdongnan and Yinggehai basins are regarded as having the best potential. The prospects are somewhat less for Taixinan, Pattani, West Natuna, Mekong, Beibuwan and North Palawan, and poor for Liyue and west

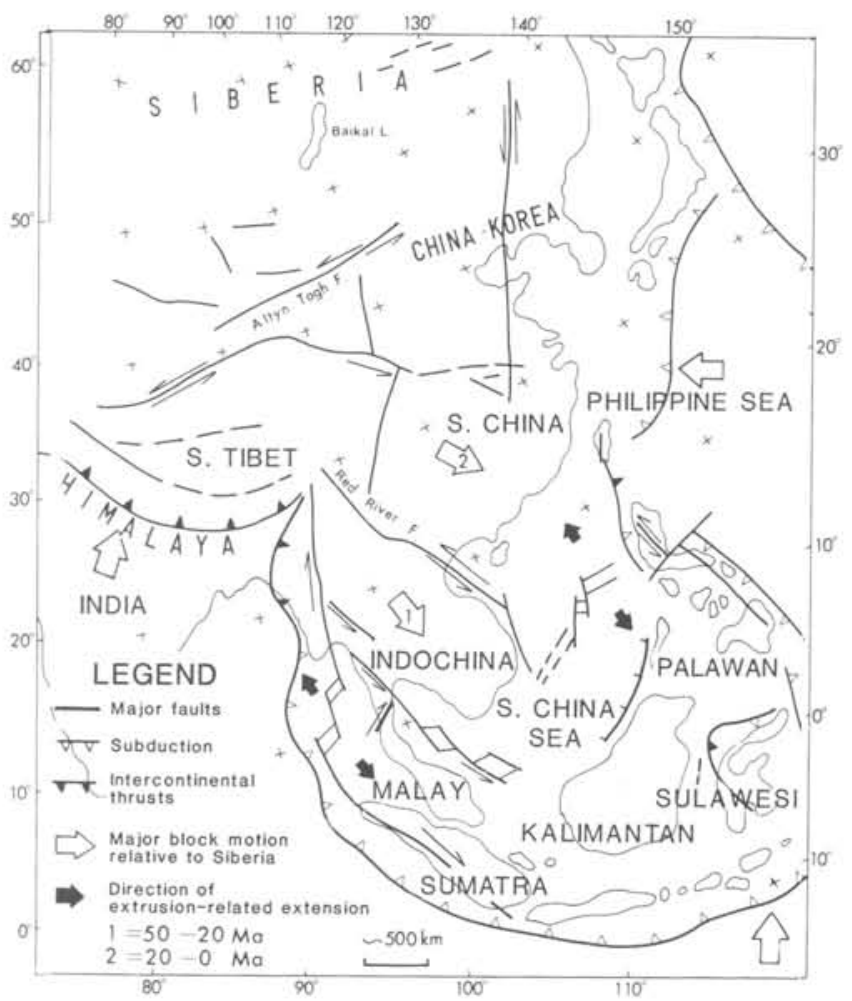

Figure 12: Major strike-slip faults of East and Southeast Asia. After Tapponnier and others (1982).
Palawan. More discoveries will undoubtedly be found as exploration efforts continuously go deeper and the number of wells increases.

\section{Acknowledgements}

The author wishes to thank the No. 2 Marine Geological Investigation Party for permission to publish this paper, and to Yang Guangtai, Chou Hua, Li Xiaoke and Li Guoying for their support and help.

Wu Jinmin has been, since 1980 , Principal Geologist and Chief of the Regional Geological Research Section of No. 2 Marine Geological Investigation Party of the Ministry of Geological and Mineral $\mathrm{Re}^{-}$ sources (P.O. Box 1180, Guangzhou, P.R. China). From 1958 to 1973 he taught at the Changchun College of Geology. Dr. Wu's research interests are in regional geology and petroleum geology, particularly of the South China Sea area.

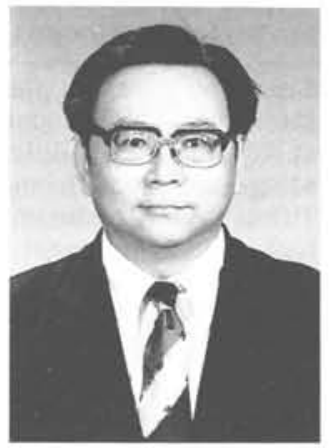

References

Armitage, J.G. and Viotti, C., 1977. Stratigraphic nomenclature - Southern end Malay Basin. Proceedings Indonesian Petroleum Association Sixth Annual Convention, v. 1, no. 6, p. 69-94. ASCOPE, 1981. Tertiary Sedimentary Basins of the Gulf of Thailand and South China Sea: Stratigraphy, Structure and Hydrocarton Occurrences. ASCOPE Secretariat, Jakarta. $72 \mathrm{p}$,

Bachman, S.B., Lewis, S.D. and Schweller, W.J., 1983. Evolution of a foreare basin, Luzor Central Valley, Philippines. American Association of Petroleum Geologists Bulletin, v. 67

Beddoes, L.R., Jr. and Valeneia, M.J., 1981. Hydrocarbon plays in Teetiary basins of Southeast Asia. Energy, v. 6, no. 11, p. 1141-1163.

CCOP-IOC SEATAR, 1980. Studies in East Asian Tectonics and Resources (SEATAR). A programme and review of research, compited for the 2nd SEATAR workshop, Bandung, 1978, $257 \mathrm{p}$.

Chou, J.T., 1971. A preliminary study of the stratignephy and sedimentation of the mudstone formations in the Tuinan area, southern Taiwan. Petroleum Geology of Taiwan, ne, R, P. $187-$ $-219$.

Chou, J.T., 1973. Sedimentology and paleogeography of the upper Cenozoic system of wester Taiwan. Proceedings of the Geological Society of China, no. 16, p. $111-143$.

Duan Weiwu and Huang Yongyang, 1987. Caleareous Nannofossil Biostratigraphy of the Tertiary in northern South China Sea. Proceedings of the International Symposium on Petroleum Geology
in Northern Continental Shelf Area of South China Sea. Compiled by Guangdong Petroleurm Society and China Oil, Guangzhou, p. 292-316.

Guo Lingzhi, Shi Yangshen and Ma Ruishi, 1983. On the formation and evolution of the Stesozoic-Cenozoic active continental margin and island are tectonies of the western Preific Ocean. Acta Geologica Sinica, v. 57, no. 1, p. 11-21.

Haile, N.S., 1974. Bornoo. In: Spencer, A.M. (ed.), Mesozoíc-Cenozoic Orogenic Belts; Data for Orogenie Studies. The Geological Society London, Special Publication no. 4, p. 333- 347.

Haile, N.W., MeEthinny, M.w, and AteDougall, t., 1977. Palaeomagnetic data and radiometric ages from the Cretaceous of west Kalimantan (Borneo), and their significance in interpretin regional structures. Journal of the Geological Society of London, v. I33, Part II. p. 133-144.

He Liansheng and Chen Bangyan (eds.), 1987. Atlas of Geology and Geophysics of South China Sea. Map Publishing House of Guangdong, 13 maps, $1: 2,000,000$, Guangzhou, P.R.China.

Hsu, i. and Seharon, L., 1970. Palaeomagnet ism of Luzon igneous rocks. Paper presented at the U.S.-Japan seminar on Paleomagnetism, Honolulu, Hawaii.

Huang Tingehang, 1982. Tertiary calcareous nannofossil stratigraphy and sedimentation cycle in Taiwan. In: Salivar-Sali, A. (ed.), Proceedings 2nd ASCOPE Conference, 1981. Manila, Philippines. Tech. Progr. Commit., ASCOPE 81, p. 873-886.

polahan, P., 1985. Petroleum exploration in Thailand. Energy, v. 10, no. 3/4, p. 475-480.

Ramili, N., 1985. The history of offshore hydrocarbon exploration in Malaysia. Energy, v. 10 , no. $3 / 4$, p. $457-473$.

Skorduti, V.A., Khudyk, T.V., Pe Vai, Nguen Ngok and Seboctyanov, K.T., 1983. Geological structure and oil of the megazone Manot depressions. Geologii Nefti I Gaza, 1983, no. 5, p. $55-60$.

Tapponnier, P., Peltzer, G., Ledain, A.Y., Arsijo, R. and Cobbold, P., 1982. Propagating extrusion tectonics in Asia - new insights from simple experiments with plasticine. Geology, v. 10 no. 12, p. $611--616$.

Woollands, M.A. and llaw, D., 1976. Tertiary stratigraphy and sedimentation in the Gulf of Thailand. SEAPEX Program, Offshore South Fast Asia Conference. South East Asia Petroleum

Wu Jinmin, 1985. The characteristies of the geological structures of the Tertiary basins on the continental mangin in the northern part of the South China Sea. Energy, v. 10, no. 3/4, p. 359-372.

Wu Jinmin, 1987. Types of Cenozoic Sedimentary Basins in South China Set and their Hydrocarbon potential Proceedings of the hternational Symposium on Petroleum Geology in Northem Continental Sheif area of South chinn Sea. Compiled by Guansdong Petroleum Society and China Oil, Guangzhou, p. $130-174$.

Zhai Cuangmin and giu Zhongjian, 1984. The characteristies of petroleum geology and hydroleum Congress, v. I, Petroleum Geology. Petroleum industry Publishing House, p. 240-248. 